\title{
Universal Design for Learning (UDL): A Content Analysis of Peer- Reviewed Journal Papers from 2012 to 2015
}

\begin{abstract}
Ahmed Al-Azawei ${ }^{1}$, Fabio Serenelli ${ }^{2}$, and Karsten Lundqvist ${ }^{3}$
Abstract: The Universal Design for Learning (UDL) framework is increasingly drawing the attention of researchers and educators as an effective solution for filling the gap between learner ability and individual differences. This study aims to analyse the content of twelve papers, where the UDL was adopted. The articles were chosen from several databases and journals based on four criteria: 1) peerreviewed papers, 2) provision of empirical results, 3) focused on UDL as a framework, and 4) published from 2012 to 2015. Then, these studies were analysed according to seven themes: type of results, study beneficiary (learners, teachers, both), sample features, geographical region, data collection techniques, data analysis techniques, and learning modes. Most of the selected studies applied the UDL in a traditional or a blended learning mode, whereas only two studies evaluated its effectiveness in online learning environments. It is noteworthy that the majority of the experiments were carried out in the USA. Additionally, positive results of UDL implementation were yielded in eleven papers. These outcomes suggest that UDL is an efficient approach for designing flexible learning environments and accessible content. Such designs can match a wide mix of learner needs, abilities, background knowledge, educational experience, and cultural differences. However, further research is required in order to confirm the positive impacts of UDL in different educational settings and cultural backgrounds.
\end{abstract}

Keywords: Universal Design for Learning (UDL), Content Review, Accessibility, Individual Differences

Learners naturally have different characteristics, preferences, needs, and abilities. Such individual features may affect their academic performance and learning experience. According to Burgstahler (2011), learner diversity also comprises physical, visual, hearing, sensory, attention, and communication impairments. From a human rights perspective, however, such limitations should not deprive people from equal opportunities in education. According to the United Nations (2006, article 24a), "Persons with disabilities are not excluded from the general education system on the basis of disability, and [that] children with disabilities are not excluded from free and compulsory primary education, or from secondary education, on the basis of disability". As such, direct teaching based on a 'one-size-fits-all' approach cannot successfully accommodate individual differences.

\footnotetext{
${ }^{1}$ School of Systems Engineering, University of Reading, Reading, Berkshire, RG6 6AH, United Kingdom, a.alazawei@pgr.reading.ac.uk.

${ }^{2}$ School of Systems Engineering, University of Reading, Reading, Berkshire, RG6 6AH, United Kingdom, f.serenelli@ reading.ac.uk.

3 School of Systems Engineering, University of Reading, Reading, Berkshire, RG6 6AH, United Kingdom, k.o.lundqvist@ reading.ac.uk.
} 
Two popular perspectives have been developed to tackle this issue. The first one is called Learning Styles Theory (LST), which suggests individualising learning content and/or pathway in accordance with learner preferences. This theory has attracted a considerable amount of attention from educational psychologists and instructional designers (Akbulut \& Cardak, 2012; Al-Azawei \& Lundqvist, 2015; Özyurt \& Özyurt, 2015; Truong, 2015). Pashler, Mcdaniel, Rohrer, \& Bjork (2009) used the term 'meshing hypothesis' to demonstrate that the key concept of LST is matching teaching and learning styles in order to promote a meaningful learning experience. Hence, LST has been widely integrated into adaptive educational hypermedia systems (AEHSs) in order to respond to individual learning styles (Akbulut \& Cardak, 2012; Özyurt \& Özyurt, 2015; Truong, 2015). However, the pedagogical implications of this educational psychology framework on instructional practice are far from being universally accepted (Akbulut \& Cardak, 2012; AlAzawei, Al-bermani, \& Lundqvist, 2016; Al-Azawei \& Lundqvist, 2015; Coffield, Moseley, Hall, \& Ecclestone, 2004; Mayer, 2011; Pashler, et al., 2009).

Many issues emerge from the critique of LST. There is the less-than-clear definition among psychologists and educationalists (Graf, 2007). According to Felder (1996), learning styles mean "characteristic strengths and preferences in the ways they [learners] take in and process information". This interlocks the terminologies of cognitive styles and learning approaches (AlAzawei \& Badii, 2014; Graf, 2007; Vanderheyden \& De Baets, 2015). Furthermore, presenting learning materials according to student learning preferences is not necessarily the best instructional choice, for instance, only written or audio materials for verbal learners have a reduced effectiveness for content that requires a visual representation due to the relationship between the type of materials and a subject nature. Other debates exist with regard to the absence of an accurate measurement to diagnose learning styles and the lack of empirical research to confirm the significance of its implications (Al-Azawei \& Lundqvist, 2015; Coffield et al., 2004; Mayer, 2011; Pashler et al., 2009; Willingham, Hughes, \& Dobolyi, 2015). Considering such shortcomings, Pashler et al. (2009) concluded that "there is no adequate evidence base to incorporate learning styles assessments into general educational practice". In summary, the empirical studies showed contradictory findings regarding the implications of learning styles on different learning aspects such as achievement, satisfaction, engagement, and learning time.

A far more comprehensive point of view is provided by the Universal Design for Learning (UDL). This framework was inspired by the Universal Design (UD) principles (Rose \& Meyer, 2002). According to Rose, Harbour, Johnston, Daley, \& Abarbanell (2006), UDL attempts to tackle the limitations of a learning environment rather than addressing learner limitations. This approach is progressively gaining consensus, particularly in the USA. UDL researchers suggest that designing 'accessible' content and delivering it in an 'accessible' learning environment can improve learning experience regardless of individual learning abilities. Although UDL assumes that learning is a unique process, it focuses on curricula design techniques to minimise the implications of learner differences (Courey, Tappe, Siker, \& LePage, 2012). Accordingly, UDL is thought to be significant in different learning settings as empirical research has delivered promising results from UDL adoption in terms of academic performance and learner perceptions (Burgstahler, 2011; Rao, Ok, \& Bryant, 2014). On the other hand, prior meta-analysis has shown that the framework has not gained real momentum yet, where it has been mainly adopted in the USA (Mangiatordi \& Serenelli, 2013).

Ultimately, LST and UDL aim to reduce learning barriers, albeit from different angles. Whilst LST suggests overcoming learner deficits by serving his/her individual preferences and focusing on the design of instructional content, the UDL aims to move from a 'teacher-centred' to

Journal of the Scholarship of Teaching and Learning, Vol. 16, No. 3, June 2016. josotl.indiana.edu [Type here] 
a 'learner-centred' approach by providing multiple means of content representation, knowledge expression, and learner engagement. Moreover, UDL is more inclined to tackle accessibility issues, promote learner inclusion, and keep students together without segregation based on their diverse abilities. In other words, UDL seeks to address learning limitations from a wider perspective, whereas the empirical application of LST takes into consideration the content design only.

\section{Background}

The term Universal Design (UD) was coined by Ronald Mace in the 1970's to refer to "the design of products and environments to be usable by all people, to the greatest extent possible, without the need for adaptation or specialized design" (Center for Universal Design, 2015). Embracing Universal Design (UD) in architecture assists disabled people to use buildings as others and without the need for retrofitting. This framework includes seven basic principles:

- Equitable use: people diversity and ability should be taken into account in the design process.

- Flexibility in use: individual preferences and abilities should be served.

- Simple and intuitive use: the design should be easily understood regardless of user prior experience and knowledge.

- Perceptible information: the design should communicate necessary information effectively to all users irrespective of their ambient conditions or sensory abilities.

- Tolerance for error: the design should reduce and minimise risks and errors of unintended actions.

- Low physical effort: the design should minimise the required physical effort to be used efficiently and comfortably.

- Size and space for approach and use: the design should provide an appropriate size and space irrespective of user's body size, posture, and/or mobility.

Other synonyms for 'Universal Design' are 'Inclusive Design' as known in the UK and 'Design for All' as known in the majority of Europe (John Clarkson \& Coleman, 2015). Based on UD concepts, three frameworks have been proposed for designing accessible learning. These are Universal Design of Instruction (UDI), Universal Instructional Design (UID), and Universal Design for Learning (UDL) (Rao et al., 2014).

UDL has been revised over the years to propose UDL 2.0 in 2011 (CAST, 2011). The Center for Applied Special Technology (CAST) defines UDL as "a framework that addresses the primary barrier to fostering expert learners within instructional environments: inflexible, "onesize-fits-all" curricula. It is inflexible curricula that raise unintentional barriers to learning" (CAST, 2011, p. 4). CAST argues that "barriers to learning are not, in fact, inherent in the capacities of learners. Instead barriers to learning arise in learners' interactions with inflexible educational goals, materials, methods, and assessments" (CAST, 2015)

The UDL evidence-based principles are grounded on the findings of neuroscience, where the human brain activates three main neural networks during any instructional experience (CAST, 2015). The framework can be divided into two layers: the conceptual layer (three networks) and the implementation layer (three principles). The three networks are defined as follows:

Journal of the Scholarship of Teaching and Learning, Vol. 16, No. 3, June 2016.

josotl.indiana.edu [Type here] 
- Recognition network: this represents the 'what' of learning. Learners use different ways to categorise what they see, hear, and read.

- Strategic network: this represents the 'how' of learning. Learners use different ways to organise and express their thoughts and ideas.

- Affective network: this represents the 'why' of learning. Different ways can be applied to engage learners and keep them excited and interested.

In 2002, CAST researchers theorised a set of three principles in order to correspond to the three learning networks. The key concepts underlying these principles are in adopting multiple means of content delivery, diverse methods of expression and assessment, and different means of engagement (Rose \& Meyer, 2002). These three principles include nine guidelines, and 31 checkpoints to be followed in order to foster this model:

- Provide multiple means of representations: this principle suggests presenting learning content in different ways, for instance, video, audio, text, graphs, and other multimedia. This can provide better opportunities not only for disabled learners, but for others as well.

- Provide multiple means of action and expression: most learners do not prefer the exclusive use of exams to assess their understanding and knowledge, because of the restricted time and organisational setting of this measurement. Therefore, asking students to express their knowledge in other formats such as assignments, interviews, short quizzes, scientific papers, and multimedia presentations can reflect their knowledge more effectively than using one measurement.

- Provide multiple means of engagement: using only a lecture format may negatively affect learner engagement. Hence, in order to maintain levels of interest during the active-lecture, other strategies can sustain student motivation, for example, delivering learning content by open discussion, Q\&A sessions, peer-tutoring, and an applied problem-solving approach.

Figure 1 illustrates the main networks and principles of the UDL.

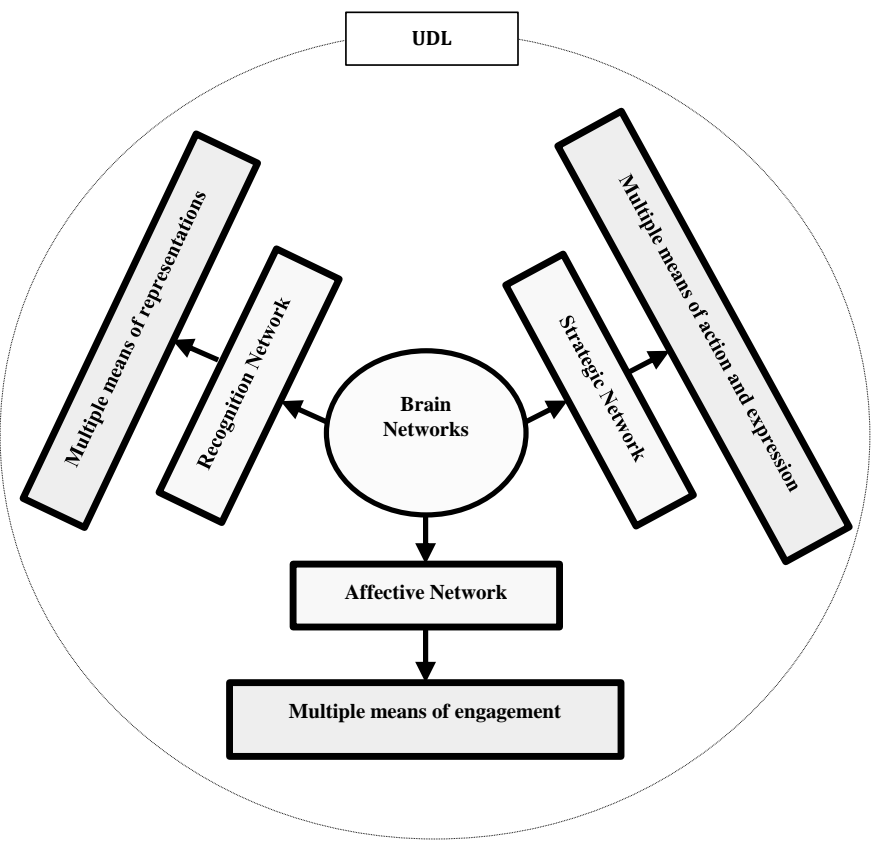

Journal of the Scholarship of Teaching and Learning, Vol. 16, No. 3, June 2016. josotl.indiana.edu [Type here] 


\section{Figure 1. The UDL framework The Research Scope}

The present study is a complementary analysis to the literature reviews conducted by Mangiatordi \& Serenelli (2013) and Rao et al. (2014). These studies examined the soundness of UDL in terms of evidence-based results. In the former review, however, the main limitations pertained to the reliance on abstracts and the usage of solely one database (ERIC, $N=80$ ). In the latter, on the other hand, other universal design frameworks such as Universal Design of Instruction (UDI) and Universal Instructional Design (UID) were included, and all reviewed papers were produced between 2005 and 2011. Hence, Rao et al. (2014) recommended that researchers need to carry out another systematic review in order to update their findings and investigate other empirical studies that were not included in their analysis. Accordingly, this research attempts to overcome the limitations of the first study and complement the findings of the second one. It considered full papers, dated from 2012 to 2015, included empirical results, and focused on UDL framework only.

\section{Inclusion Criteria}

According to Liyanagunawardena, Adams, \& Williams (2013), different methods can be used to identify relevant work for a review study such as searching in databases and search engines. In order to systematically retrieve relevant papers, we applied the four steps of the method that was suggested by Chekfoung, Lily, \& Kecheng (2015). However, the inclusion criteria and classification themes were adapted in accordance with the aim and nature of this study.

One primary keyword was used to retrieve relevant work which was: "Universal Design for Learning" with quotations. This is to simplify the research and make it repeatable. The ERIC and IEEE Xplore databases, Google Scholar search engine, Science Direct, ACM, and International Review of Research in Open and Distributed Learning (IRRODL) journals were used to obtain peer-reviewed papers. This search was carried out in May 2015. The number of the retrieved papers from these sources is illustrated in Table 1. Based on the goal of the study, we identified four inclusion criteria:

1. Peer-reviewed papers;

2. Papers with empirical results;

3. Papers that used UDL as a framework;

4. The publication date is from 2012 to 2015 .

Table 1. The selected databases and journals

\begin{tabular}{|l|c|c|}
\hline Database or Journal & Search Results & Relevant \\
\hline ERIC & 28 & 7 \\
\hline IEEE Xplore & 2 & 0 \\
\hline Google Scholar & 21 & 5 \\
\hline ACM & 2 & 0 \\
\hline Science Direct & 1 & 0 \\
\hline IRRODL & 1 & 0 \\
\hline
\end{tabular}

Some papers were not fully downloaded by our browser linked to the university library because there is a cost associated with these articles. This led to their exclusion from this review 
since the aim was not to analyse the abstracts only, but the entire content. Initially, 55 peerreviewed papers were retrieved (after removing duplicated papers $\mathrm{N}=5$ ). The researchers carefully reviewed the abstracts, conclusions, and skimmed the content in order to select the most suitable papers according to the identified criteria. A total of 17 out of 55 articles were chosen to be reviewed. However, during the review process, 5 papers were also excluded because they did not contain findings from their empirical work, or only proposed a framework that integrated this model. As a result, 12 papers were selected to be included in this review. All papers were analysed in accordance with seven themes. Figure 2 depicts the research strategy and the identified exclusion criteria and analysis themes.

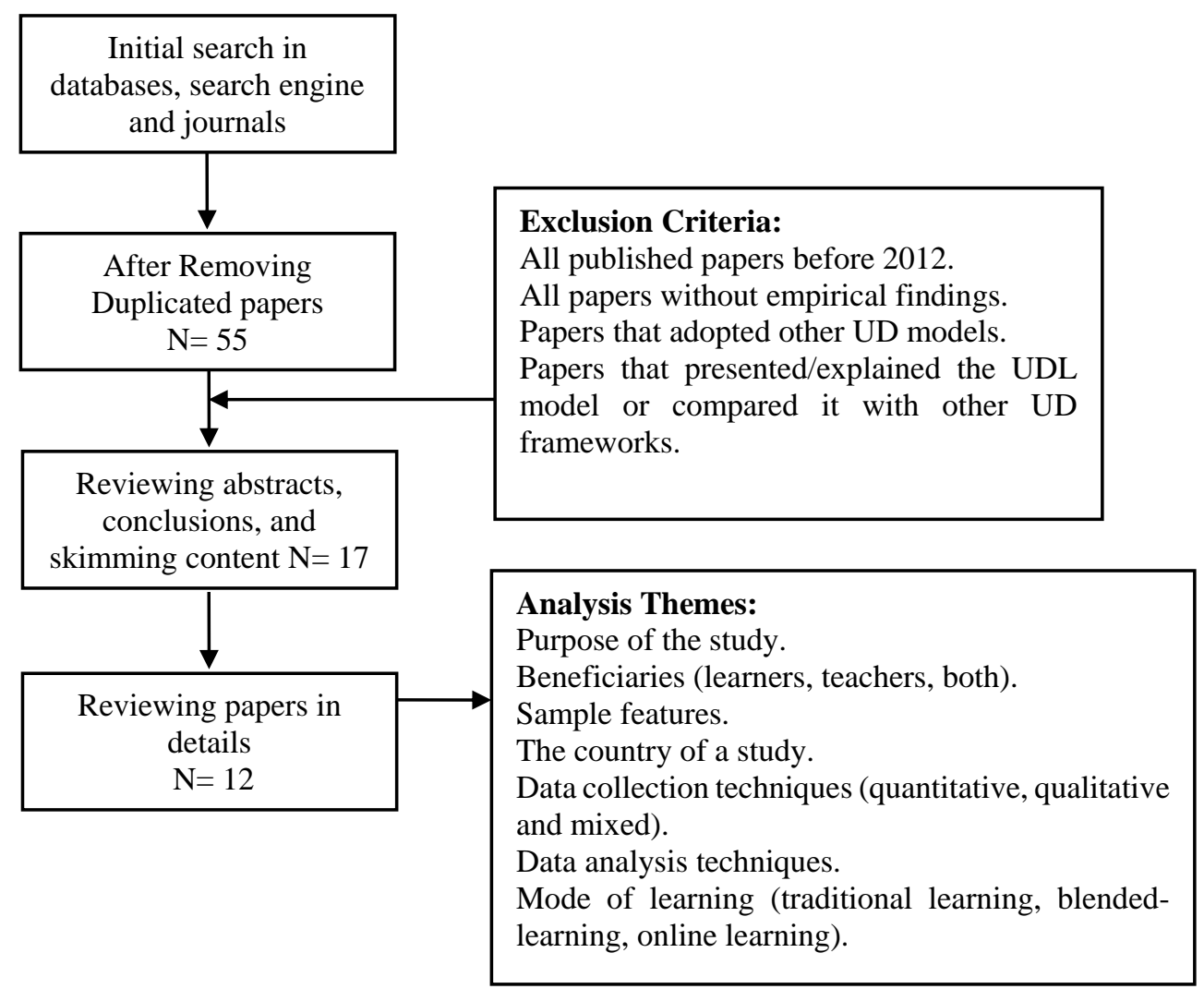

Figure 2. The research strategy.

\section{Results}

This study sought to verify the UDL implications on user experience, academic performance, and educational contexts. Moreover, it identified research gaps in the current UDL implementation. Papers were selected in accordance with four criteria, and they were analysed based on seven themes. This section presents the main findings of this review according to the selected themes.

The objectives of prior literature were categorised into four groups: (1) Measuring learner perceptions, (2) Performance evaluation, (3) Developing lesson plans, and (4) Exploring curricula alignment to UDL principles either automatically (Smith \& Harvey, 2014) or manually (Mavrou \& Symeonidou, 2014). Some studies were designed to measure more than one goal, for example, 
to investigate the impact of embracing UDL on learner performance and perceptions (Hall, Cohen, Vue, \& Ganley, 2015), learner perceptions and teacher experience (Kumar \& Wideman, 2014), and the synergy between UDL-based teacher training programs and student perceptions (Davies et al., 2012).

Beneficiaries of UDL integration included both learners and teachers, as well as educational institutions. The majority of studies showed that a UDL-inspired course design positively affects user perceptions and/or academic performance. In the study conducted by Hall et al. (2015), the improvement of learner performance was attributed to UDL application. Coyne et al. (2012) illustrated that successful implementation of UDL can promote the reading comprehension of learners with significant intellectual disabilities. The effectiveness of UDL adoption on student performance with particular disabilities was also indicated by Kennedy et al. (2014). King-Sears et al. (2015), however, did not find a significant difference in academic achievement between control and experimental groups, but results did support the positive influence of UDL on learner perceptions. Similarly, a curriculum-based UDL integration was shown to promote learner engagement, satisfaction, and self-efficacy (Davies et al., 2012; KingSears et al., 2015; Smith, 2012). Hall et al. (2015) noted that disabled learners highly enjoyed using a UDL-based online learning tool to improve reading comprehension. Additionally, He (2014) revealed that fostering UDL through online courses can decrease learner concerns and anxiety, and promote perceived satisfaction. Finally, it was also established that designing a course according to UDL principles can positively affect learning flexibility and success, reduce learning stress, and enhance the social presence of learners (Kumar \& Wideman, 2014).

Furthermore, the specialised programs on UDL instructional design techniques assisted tutors in adapting their teaching strategies to fit all learners, practice their individual teaching experience in diverse ways, and transform their teaching styles for a wide mix of students. Two studies depicted that teachers highly benefited from a UDL-based training programs in order to design and improve curricula accessibility (Courey et al., 2012; McGhie-Richmond \& Sung, 2012).

Other studies supported the positive effect of UDL implementation on both teachers and students (Davies et al., 2012; Hall et al., 2015; Kumar \& Wideman, 2014). Kumar \& Wideman (2014) pointed out that a UDL-based course design can promote teacher engagement and reduce their workload because the implementation of UDL can lead students to practicing a 'learnercentred' approach rather than relying solely on the traditional 'teacher-centred' method.

Finally, two papers revealed how educational institutions can benefit from UDL principles in designing flexible and accessible curricula (Mavrou \& Symeonidou, 2014; Smith \& Harvey, 2014). Moreover, Kumar \& Wideman (2014) established that the required intervention by a disability services department of an educational institution can also be reduced when UDL is applied. It is worth mentioning that the implications of UDL are not limited to a particular discipline. Positive impacts were observed in different disciplines such as psychology (Davies et al., 2012), language learning (Coyne et al., 2012; Hall et al., 2015; Kennedy et al., 2014), and chemistry (King-Sears et al., 2015; Kumar \& Wideman, 2014).

Pertaining to sample features, UDL was applied to different learning contexts and for all educational levels, ranging from pre-school children to graduate students. Generally, studies did not entail thorough demographic and background information of subjects. Six experiments provided details about sample disabilities, where ethnicity groups were identified in five studies (Coyne, Pisha, Dalton, Zeph, \& Smith, 2012; Courey et al., 2012; Hall et al., 2015; Kennedy, Thomas, Meyer, Alves, \& Lloyd, 2014; King-Sears et al., 2015), age was reported in four studies,

Journal of the Scholarship of Teaching and Learning, Vol. 16, No. 3, June 2016.

josotl.indiana.edu [Type here] 
and five papers failed to include gender differences. Furthermore, as stated by Davies et al. (2012), a control group versus an intervention group methodology is an advisable approach in order to compare results and reveal the potential significance of the model. The targeted samples were divided into experimental and control groups in four interventions (Coyne et al., 2012; Davies et al., 2012; Kennedy et al., 2014; King-Sears et al., 2015). Out of these studies, only King-Sears et al. (2015) failed to establish a significant difference between their academic achievement. Table 2 summarises the detailed background information of the samples.

Table 2. Demographic information of samples

\begin{tabular}{|l|c|c|c|c|c|}
\hline Study & Sample & Male & Female & Age & Disability \\
\hline Davies et al. (2012) & 386 & - & - & - & 54 \\
\hline Coyne et al. (2012) & 16 & 11 & 5 & - & 16 \\
\hline Courey et al. (2012) & 45 & - & - & $23-53$ & - \\
\hline McGhie-Richmond \& Sung (2012) & 26 & - & - & - & - \\
\hline Smith (2012) & 80 & - & - & $20-34$ & - \\
\hline Kumar \& Wideman (2014) & 35 & - & - & - & 2 \\
\hline He (2014) & 24 & 7 & 17 & - & - \\
\hline Kennedy et al. (2014) & 141 & $76 \%$ & $24 \%$ & M (16.9) & 32 \\
\hline King-Sears et al. (2015) & 60 & 25 & 35 & & 19 \\
\hline Hall et al. (2015) & 284 & 144 & 140 & M (11.6) & 64 \\
\hline
\end{tabular}

With regard to the geographical location of these experiments, the majority of them were limited to a few countries, with learners who have similar cultural and socioeconomic backgrounds. This analysis showed that nine studies were performed in the USA, two in Canada (Kumar \& Wideman, 2014; McGhie-Richmond \& Sung, 2012), and one in Greece (Mavrou \& Symeonidou, 2014). This finding is consistent with the study of Mangiatordi \& Serenelli (2013). In their review, it was found that most empirical studies were conducted in North America, whereas a very small amount of research was performed in other countries (twenty seven in the USA, two in Singapore, one in Australia, and one in Brunei). Thus, we can safely state that the UDL does not seem to be a 'universally' accepted approach.

Different techniques were used to collect data in the reviewed articles. The majority of them relied on a pure quantitative method. In contrast, Mavrou \& Symeonidou (2014) used a qualitative design only, whereas a mixed approach was applied in five experiments (Hall et al., 2015; He, 2014; Kumar \& Wideman, 2014; McGhie-Richmond \& Sung, 2012; Smith, 2012). Based on the data collection methods, data analysis included either statistical tests for quantitative data or integrating a thematic technique for qualitative analysis. Examples of the used inferential statistical tests are t-test, ANOVA, MANOVA, and MANCOVA.

The advantages of UDL are not restricted to a particular learning mode. However, most interventions took place in a traditional classroom setting (four papers) or blended learning environments (five papers). One experiment examined the model in a synchronous and an asynchronous online setting (He, 2014). Hall et al. (2015) compared a UDL-based online learning tools with a UDL-based traditional learning modes. Smith \& Harvey (2014), on the other hand, analysed the alignment of online resources in Khan Academy according to UDL principles. Table 3 summarises the main findings of this analysis.

Journal of the Scholarship of Teaching and Learning, Vol. 16, No. 3, June 2016.

josotl.indiana.edu [Type here] 
Table 3. Results summary

\begin{tabular}{|c|c|c|}
\hline Theme & Number & $\%$ \\
\hline \multicolumn{3}{|l|}{ Purpose } \\
\hline Measuring learner perceptions & 4 & 33.33 \\
\hline Measuring learner performance & 4 & 33.33 \\
\hline Developing lesson plans & 2 & 16.66 \\
\hline Alignment of lessons design to UDL & 2 & 16.66 \\
\hline \multicolumn{3}{|l|}{ Sample } \\
\hline Post K-12 & 8 & 66.66 \\
\hline Pre K-12 & 4 & 33.33 \\
\hline \multicolumn{3}{|l|}{ Beneficiary } \\
\hline Students & 5 & 41.66 \\
\hline Teachers & 2 & 16.66 \\
\hline Both & 3 & 25 \\
\hline Educational institutes & 2 & 16.66 \\
\hline \multicolumn{3}{|l|}{ Region of study } \\
\hline USA & 9 & 75 \\
\hline Canada & 2 & 16.66 \\
\hline Greece & 1 & 8.33 \\
\hline \multicolumn{3}{|l|}{ Data collection technique } \\
\hline Quantitative & 6 & 50 \\
\hline Qualitative & 1 & 8.33 \\
\hline Mixed & 5 & 41.66 \\
\hline \multicolumn{3}{|l|}{ Data analysis technique } \\
\hline Quantitative & 6 & 50 \\
\hline Qualitative & 1 & 8.33 \\
\hline Mixed & 5 & 41.66 \\
\hline \multicolumn{3}{|l|}{ Learning mode } \\
\hline Traditional & 4 & 33.33 \\
\hline Blended & 6 & 50 \\
\hline Online & 2 & 16.66 \\
\hline
\end{tabular}

The reviewed literature is classified into post k-12 and pre k-12 and chronologically summarised in Tables 4a, 4b, and 5 in order to provide more details about their purposes, samples, methods, and findings.

Journal of the Scholarship of Teaching and Learning, Vol. 16, No. 3, June 2016. 
Table 4a. Post K-12

\begin{tabular}{|c|c|c|c|c|}
\hline Study & Purpose & Sample & Method & Finding \\
\hline $\begin{array}{l}\text { Davies et al. } \\
(2012)\end{array}$ & $\begin{array}{l}\text { This study } \\
\text { measured the } \\
\text { effectiveness of } \\
\text { instructor-led } \\
\text { training with } \\
\text { regard to the } \\
\text { principles of } \\
\text { UDL and then it } \\
\text { investigated } \\
\text { student } \\
\text { perceptions }\end{array}$ & $\begin{array}{l}\text { Teachers and k-12 } \\
\text { students. }\end{array}$ & $\begin{array}{l}\text { Participants were } \\
\text { divided into } \\
\text { intervention and } \\
\text { control groups. They } \\
\text { filled out pre and } \\
\text { post questionnaires. }\end{array}$ & $\begin{array}{l}\text { A positive } \\
\text { significant change } \\
\text { was shown in } \\
\text { learner perceptions } \\
\text { after applying UDL. }\end{array}$ \\
\hline $\begin{array}{l}\text { Courey et al. } \\
(2012)\end{array}$ & $\begin{array}{l}\text { Examining how } \\
\text { candidate } \\
\text { teachers can } \\
\text { understand and } \\
\text { apply the } \\
\text { principles of } \\
\text { UDL in their } \\
\text { lesson plans }\end{array}$ & Teacher candidate & $\begin{array}{l}\text { Three-hour training } \\
\text { course about the } \\
\text { principles of UDL. } \\
\text { Researchers assessed } \\
\text { the lesson plans of } \\
\text { the sample before } \\
\text { and after the training } \\
\text { session. }\end{array}$ & $\begin{array}{l}\text { A significant } \\
\text { improvement in } \\
\text { lesson plan design } \\
\text { was demonstrated. }\end{array}$ \\
\hline $\begin{array}{l}\text { McGhie- } \\
\text { Richmond \& } \\
\text { Sung (2012) }\end{array}$ & $\begin{array}{l}\text { Investigating } \\
\text { how candidate } \\
\text { teachers can } \\
\text { understand and } \\
\text { apply the } \\
\text { principles of } \\
\text { UDL in their } \\
\text { lesson plan }\end{array}$ & Teacher candidate & $\begin{array}{l}\text { A brief introduction } \\
\text { was conducted about } \\
\text { the principles of } \\
\text { UDL. Then, } \\
\text { participants were } \\
\text { requested to assess a } \\
\text { lesson plan } \\
\text { according to UDL } \\
\text { principles. }\end{array}$ & $\begin{array}{l}\text { Quantitative results } \\
\text { showed that } \\
\text { participants made } \\
\text { substantial changes, } \\
\text { but no significant } \\
\text { differences. } \\
\text { However, they } \\
\text { benefited from the } \\
\text { framework as } \\
\text { indicated by the } \\
\text { qualitative results. }\end{array}$ \\
\hline Smith (2012) & $\begin{array}{l}\text { Examining } \\
\text { learner } \\
\text { perceptions after } \\
\text { adopting UDL } \\
\text { principles }\end{array}$ & Graduate students & $\begin{array}{l}\text { The course was } \\
\text { designed according } \\
\text { to the UDL } \\
\text { guideline. At the end } \\
\text { of the course, } \\
\text { students were asked } \\
\text { to describe their } \\
\text { perceptions through } \\
\text { a survey }\end{array}$ & $\begin{array}{l}\text { The study showed } \\
\text { the importance of } \\
\text { adopting UDL } \\
\text { because it } \\
\text { significantly } \\
\text { affected learner } \\
\text { perceptions. }\end{array}$ \\
\hline
\end{tabular}

Journal of the Scholarship of Teaching and Learning, Vol. 16, No. 3, June 2016. josotl.indiana.edu [Type here] 
Table 4b. Post K-12

\begin{tabular}{|c|c|c|c|c|}
\hline Study & Purpose & Sample & Method & Finding \\
\hline $\mathrm{He}(2014)$ & $\begin{array}{l}\text { Investigating } \\
\text { learner } \\
\text { perceptions in a } \\
\text { web-based } \\
\text { learning course }\end{array}$ & $\begin{array}{l}\text { Teacher } \\
\text { candidates }\end{array}$ & $\begin{array}{l}\text { The three principles of } \\
\text { UDL were applied in the } \\
\text { online course. Pre and } \\
\text { post surveys, as well as } \\
\text { open-ended questions, } \\
\text { were used to measure } \\
\text { learner perceptions. }\end{array}$ & $\begin{array}{l}\text { Participants showed their } \\
\text { satisfaction about the } \\
\text { course and how it helped } \\
\text { to improve their self- } \\
\text { efficacy and confidence } \\
\text { in online learning. }\end{array}$ \\
\hline $\begin{array}{l}\text { Kennedy et } \\
\text { al. (2014) }\end{array}$ & $\begin{array}{l}\text { To improve } \\
\text { learner abilities } \\
\text { in vocabulary } \\
\text { instructions } \\
\text { using UDL and } \\
\text { Mayer's } \\
\text { principles of } \\
\text { designing } \\
\text { instructional }\end{array}$ & $\begin{array}{l}\text { Undergraduate } \\
\text { students }\end{array}$ & $\begin{array}{l}\text { Students were } \\
\text { distributed into two } \\
\text { groups with and without } \\
\text { disabilities. All } \\
\text { participants did pre and } \\
\text { post-tests in order to } \\
\text { compare results. }\end{array}$ & $\begin{array}{l}\text { Students did significantly } \\
\text { better after designing the } \\
\text { program according to } \\
\text { UDL principles. } \\
\text { Additionally, the learning } \\
\text { gap between students } \\
\text { with and without } \\
\text { disabilities was reduced. }\end{array}$ \\
\hline $\begin{array}{l}\text { Kumar \& } \\
\text { Wideman } \\
(2014)\end{array}$ & $\begin{array}{l}\text { To improve } \\
\text { technology } \\
\text { enhanced a } \\
\text { face-to-face } \\
\text { health science } \\
\text { course }\end{array}$ & $\begin{array}{l}\text { Undergraduate } \\
\text { students }\end{array}$ & $\begin{array}{l}\text { Students were unaware } \\
\text { about designing the } \\
\text { course according to the } \\
\text { principles of UDL until } \\
\text { the end of the course. } \\
\text { Then, they were } \\
\text { requested to fill out a } \\
\text { survey and to participate } \\
\text { in a semi-structured } \\
\text { interview. }\end{array}$ & $\begin{array}{l}\text { Students indicated their } \\
\text { satisfaction regarding the } \\
\text { course because it } \\
\text { provided them with more } \\
\text { flexibility, reduced } \\
\text { learning stress, and } \\
\text { enhanced success and } \\
\text { social presence. The study } \\
\text { also revealed that the } \\
\text { instructor and the } \\
\text { disability service provider } \\
\text { at the university were } \\
\text { highly satisfied because } \\
\text { the implementation of } \\
\text { UDL can reduce the effort } \\
\text { of both teachers and the } \\
\text { disability service } \\
\text { providers. }\end{array}$ \\
\hline $\begin{array}{l}\text { Smith \& } \\
\text { Harvey } \\
(2014)\end{array}$ & $\begin{array}{l}\text { To evaluate if } \\
\text { the lessons' } \\
\text { content in an } \\
\text { online library } \\
\text { was designed } \\
\text { according to the } \\
\text { UDL guideline } \\
\text { or not (degree of } \\
\text { conformance/ } \\
\text { compliance) }\end{array}$ & - & $\begin{array}{l}478 \text { lessons were } \\
\text { randomly selected from } \\
\text { Khan Academy lessons. }\end{array}$ & $\begin{array}{l}\text { Results did not show that } \\
\text { the library's lessons were } \\
\text { fostering UDL principles. }\end{array}$ \\
\hline
\end{tabular}

Journal of the Scholarship of Teaching and Learning, Vol. 16, No. 3, June 2016. josotl.indiana.edu [Type here] 
Table 5. Pre K-12

\begin{tabular}{|c|c|c|c|c|}
\hline Study & Purpose & Sample & Method & Finding \\
\hline $\begin{array}{l}\text { Coyne et al. } \\
\text { (2012) }\end{array}$ & $\begin{array}{lr}\text { This } & \text { study } \\
\text { investigated the } & \text { th } \\
\text { influence of a UDL- } \\
\text { based learning } \\
\text { technology on } \\
\text { reading performance } \\
\text { of students with } \\
\text { intellectual } \\
\text { disabilities. }\end{array}$ & $\begin{array}{l}\text { School } \\
\text { students }\end{array}$ & $\begin{array}{l}\text { Participants were } \\
\text { classified into two } \\
\text { groups (intervention } \\
\text { and control). Then, } \\
\text { pre and post-tests } \\
\text { were administered to } \\
\text { evaluate their } \\
\text { achievements. }\end{array}$ & $\begin{array}{l}\begin{array}{l}\text { Students in experimental } \\
\text { achieved }\end{array} \\
\text { group rignificantly better than the } \\
\text { control group. This clearly } \\
\text { indicates the usefulness of } \\
\text { applying UDL to promote } \\
\text { student reading abilities. }\end{array}$ \\
\hline $\begin{array}{l}\text { Mavrou \& } \\
\text { Symeonidou } \\
(2014)\end{array}$ & $\begin{array}{l}\text { To measure the } \\
\text { conformity of Greek- } \\
\text { Cypriot NNC to UDL } \\
\text { principles. }\end{array}$ & - & 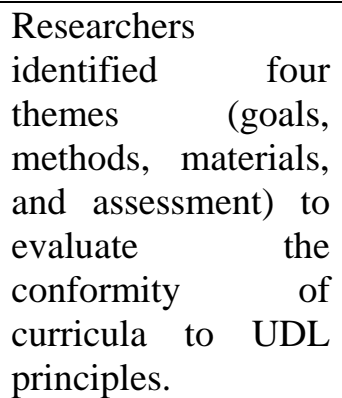 & $\begin{array}{l}\text { The results indicated that } \\
\text { the curricula design was } \\
\text { not meeting the principles } \\
\text { of UDL. }\end{array}$ \\
\hline $\begin{array}{l}\text { King-Sears } \\
\text { et al. (2015) }\end{array}$ & $\begin{array}{l}\text { To investigate the } \\
\text { effectiveness of } \\
\text { adopting UDL on } \\
\text { learner performance } \\
\text { with and without } \\
\text { disabilities. }\end{array}$ & $\begin{array}{l}\text { School } \\
\text { students }\end{array}$ & $\begin{array}{lr}\text { Students } & \text { were } \\
\text { randomly } & \text { classified } \\
\text { into two groups } \\
\text { (control } & \text { and } \\
\text { intervention). Pre, } \\
\text { post-tests, and a } \\
\text { four-week delayed } \\
\text { test } \\
\text { administered } \\
\text { measure } \\
\text { performance } \\
\text { differences between } \\
\text { the groups. Then, a } \\
\text { survey } \\
\text { distributed } \\
\text { identify } \\
\text { perceptions. }\end{array}$ & $\begin{array}{l}\text { Findings did not show a } \\
\text { significant difference in } \\
\text { terms of performance } \\
\text { between the groups. } \\
\text { However, all participant } \\
\text { perceptions in the } \\
\text { intervention group were } \\
\text { ranged from agree to } \\
\text { strongly agree which } \\
\text { suggests that there was an } \\
\text { improvement in their } \\
\text { perceptions. }\end{array}$ \\
\hline $\begin{array}{l}\text { Hall et al. } \\
(2015)\end{array}$ & $\begin{array}{l}\text { To examine the effect } \\
\text { of a strategic reader } \\
\text { tool blended UDL } \\
\text { and Curriculum- } \\
\text { Based Measurement } \\
(\mathrm{CBM}) \text { on learner } \\
\text { performance and } \\
\text { teacher strategies in }\end{array}$ & $\begin{array}{l}\text { School } \\
\text { students } \\
\text { and } 10 \\
\text { teachers }\end{array}$ & $\begin{array}{l}\text { Researchers } \\
\text { conducted pre-test } \\
\text { and post-test after } \\
\text { interventions to } \\
\text { measure student } \\
\text { abilities in reading. } \\
\text { Additionally, } \\
\text { teachers } \\
\text { interviewed were } \\
\text { and }\end{array}$ & $\begin{array}{l}\text { Both teachers and students } \\
\text { with and without } \\
\text { disabilities benefited from } \\
\text { the adoption of UDL, } \\
\text { specifically, in the online } \\
\text { treatment. The difference } \\
\text { between online and offline } \\
\text { scores was statistically } \\
\text { significant for disabled }\end{array}$ \\
\hline
\end{tabular}

Journal of the Scholarship of Teaching and Learning, Vol. 16, No. 3, June 2016. josotl.indiana.edu [Type here] 


\begin{tabular}{|l|l|l|l|l|}
\hline & $\begin{array}{l}\text { online and offline } \\
\text { treatments. }\end{array}$ & $\begin{array}{l}\text { students were asked } \\
\text { to fill out a closing } \\
\text { survey. }\end{array}$ & $\begin{array}{l}\text { learners and they indicated } \\
\text { their satisfaction and } \\
\text { engagement. }\end{array}$ \\
\hline
\end{tabular}

\section{Discussion}

The present meta-analysis review explored some of the available studies that implemented UDL as a pedagogical framework. Generally, it identified significant findings of UDL application in different learning settings. This may compensate for a major concern that was highlighted in a previous review (Mangiatordi \& Serenelli, 2013). However, the research shows that there are many opportunities and challenges in order to universally validate this framework.

Following the pinpointed inclusion criteria, the initial search of this study indicated that most of the UDL literature presented its theoretical base and importance in the educational practice, whereas only a few studies included empirical investigations.

\section{UDL implications}

Implementing UDL in education is a promising solution to minimise learning barriers. Although the amount of UDL empirical research is still in its infancy, as demonstrated in this study and previous meta-reviews (Mangiatordi \& Serenelli, 2013; Rao et al., 2014), the available findings indicate that exerting further effort to foster the UDL framework in curricula design can provide equal learning opportunities for all people.

UDL has increasingly attracted attention in education in order to design, develop, and implement a curriculum regardless of individual abilities (Smith \& Harvey, 2014). This framework can illuminate curricula delivery to a wide mix of learners, encompassing those with disabilities. The reviewed literature indicates that a UDL-based curriculum design reduces learning barriers between able and disabled students. Furthermore, examining the effectiveness of the model on disabled learners showed that UDL-inspired courses do not require special accommodation because learner needs can be considered from the start.

The improvement of learner perceptions represents another advantage of UDL implementation. Students who attended UDL-based courses possessed high satisfaction, positive attitude, and engagement in comparison to other peers. Such beliefs can encourage them to complete their courses successfully or adopt a learning technology.

Furthermore, introducing the model to teachers presents the opportunity of expanding their academic understanding and guiding them in designing more accessible and systematic courses. A UDL-based training program was shown to improve awareness of candidate teachers in developing novel teaching approaches in terms of representing the learning content, engaging students, and assessing their understanding (Courey et al., 2012). As a consequence, all students can benefit from the variety of instructional and assessment methods and this, in turn, may lead to lesson proficiency.

Findings from this study also reveal that UDL principles can be used as a comprehensive guideline by educationalists as a starting point in developing accessible curricula or for evaluating their current design. Although Khan Academy is a popular library, which offers video integrating closed captioning and audio resources for different disciplines, deep examination revealed that its online resources are not aligned with a wide range of learner abilities (Smith \& Harvey, 2014). Similarly, Mavrou \& Symeonidou (2014) successfully used the model for investigating the extent to which 'new national curricula (NNC)' that were developed for the public Greek-Cypriot 
schools, are adjusted to UDL guidelines. It was concluded that the NNC was inflexibly designed, and neither guided educators to apply multiple means of teaching methods nor provided students with alternative learning modalities.

Another important aspect of UDL adoption is its successful application to different disciplines and learning modes. Hence, using UDL principles in online learning may address many barriers that hinder its effective application in contemporary long-distance education such as Massive Open Online Courses (MOOCs). One of the main issues in available e-courses is the universal provision of instructional technique and content irrespective of learner differences, preferences, and abilities. This may be indicated in learner dissatisfaction, disinterest, and dropout from such courses. As presented in this study, successful UDL application can improve learner perceptions and this, in turn, may positively enhance students' willingness to complete their online-based modules. This, on the other hand, does not mean that UDL adoption can address all the obstacles of online learning, however, using multiple means of representation, expression, and engagement can motivate learners to achieve their learning goals more effectively and enjoyably. In the study performed by Hall et al. (2015), disabled learners in an online treatment achieved significantly higher scores than those in the traditional setting. This supports the conclusion of Liakou \& Manousou (2015) that distance learning provides an alternative learning opportunity for people with disabilities. Based on this discussion, in order to provide better learning opportunities for students with and without disabilities, there is a need for further research to align online courses in accordance with UDL principles. In summary, this model represents a promising solution in maximising the benefits of Technology Enhanced Learning (TEL) to a larger audience rather than serving particular learners.

\section{Gaps in Current UDL Research}

Regardless of the above discussed potential advantages, there are several gaps and limitations in current UDL application that should be considered.

The first issue is that the validity of UDL on a cross-cultural level remains a concern for researchers. UDL application is limited to a few countries and with samples that are from very similar cultural and socioeconomic backgrounds. As previously highlighted by Mangiatordi \& Serenelli (2013), the majority of empirical studies were conducted in North America, whereas a very small amount of experiments took place in other countries. The present research is in agreement with this argument where $75 \%$ of the reviewed studies were performed in the USA. The scarcity of empirical findings to support the model in diverse regions and cultures encourages further research to address this gap.

In addition, the terms "Conformant" and "Compliant" refer to the extent to which a particular instructional design solution embraces UDL. Hence, the extent to which the designed lessons are UDL-compliant were not clearly reported in earlier experiments. Although several studies have described how their lessons embraced UDL, none has explicitly demonstrated how many checkpoints in the UDL guideline have been applied. This outcome is compatible with the findings of Rao et al. (2014). A more in-depth investigation may reveal that some studies did not evaluate UDL conformance/compliance accurately, and this, in turn, may weaken the reliability of their findings.

Finally, the applicability of the framework is another concern. Empirical research was done or controlled by scholars from educational or psychological backgrounds. This is because instructors from other disciplines are not yet aware of UDL principles. Another reason is that the

Journal of the Scholarship of Teaching and Learning, Vol. 16, No. 3, June 2016. josotl.indiana.edu [Type here] 
adoption of all identified checkpoints in the model guideline requires a lot of effort and time. This may explain why its use is limited around the world. According to Kumar \& Wideman (2014), preparing multiple means of representation or grading learner achievement in a UDL-inspired course design requires more time than in traditional courses. Therefore, all reviewed experiments have used the main concepts of each principle as a pedagogical guide to designing a course instead of applying each checkpoint in the guideline.

\section{Recommendations and Future Research Directions}

From this analysis, many recommendations for further research are drawn. Firstly, as researchers explore the impact of UDL adoption, obstacles that could hinder its effective implementation should also be highlighted in order to overcome them in future research and fully benefit from this pedagogical framework. Moreover, there is an opportunity to examine the influence of UDL adoption on learning time where previous experiments did not consider this aspect. If learners in an experimental group absorb learning content in less time than in a control group, the model can be supported further. It is furthermore recommended that all necessary information of participants should be identified in order to show the extent to which UDL can address individual learner needs with and without disabilities. In addition, experiments that empirically compare UDL with other inclusive learning frameworks are also encouraged to cast some light on the opportunities and difficulties of adopting each one. Finally, researchers from other countries, and especially developing nations, are highly recommended to embrace this model as a possible solution to promote education systems and, thus, its validity and appropriateness across cultures can be confirmed. However, such adoption cannot be achieved without spreading the philosophy of inclusive education in these countries.

\section{Limitations}

Irrespective of the significance of the present work, many limitations have to be highlighted. The first one is that the search for relevant studies was performed only once without repeating it after a specific period. This may indicate that some papers were bypassed or published later. Moreover, only particular databases and journals were used. Consequently, studies that are indexed in other databases were not included. The last limitation is that the only keyword used for the collection of relevant papers was 'Universal Design for Learning'. However, using a combination of keywords may retrieve better results. As such, we highly recommend other scholars integrating a greater range of databases and other keywords to expand the findings of this research.

\section{Conclusion}

The traditional teaching approach of 'one-size-fits-all' cannot meet learner diversity in contemporary learning. The main theories that have been developed to overcome the failing of this approach are either accommodating educational content in accordance with individual learner preferences or designing flexible and accessible educational settings, without retrofitting or adaptation. The former can be exhibited in the learning styles theory, whereas the UDL approach represents the latter.

The present investigation reviewed some of the prior studies on UDL from 2012 to 2015. This led to the identification of the current trends and gaps in UDL research. Although the 
examined papers supported the effectiveness of this framework to design accessible learning environments, some limitations in the UDL implementation should also be considered. Moreover, more effort should be put into providing adequate evidence regarding the appropriateness and applicability of UDL, especially in developing countries.

This study represents the first step of continuous research in understanding the soundness of UDL application in developing nations. We hope that our future research will constitute a serious contribution to enhancing flexibility and accessibility within higher education for such nations.

\section{Acknowledgment}

The authors are grateful to the Iraqi Ministry of Higher Education and Scientific Research for sponsoring this study. They would also like to thank Dr. Lina P. Varotsi for her insightful comments on the earlier version of the research.

\section{References}

Akbulut, Y., \& Cardak, C. S. (2012). Adaptive educational hypermedia accommodating learning styles: A content analysis of publications from 2000 to 2011. Computers \& Education, 58(2), 835842. doi:10.1016/j.compedu.2011.10.008

Al-Azawei, A., \& Badii, A. (2014). State of The Art of Learning Styles-Based Adaptive Educational Hypermedia Systems (LS-BAEHSs). International Journal of Computer Science and Information Technology, 6(3), 1-19. doi:10.5121/ijcsit.2014.6301

Al-Azawei, A., Al-bermani, A., \& Lundqvist, K. (2016). Evaluating the Effect of Arabic Engineering Students' Learning Styles in Blended Programming Courses. Journal of Information Technology Education: Research, 15, 109-130.

Al-Azawei, A., \& Lundqvist, K. (2015). Learner Differences in Perceived Satisfaction of an Online Learning: an Extension to the Technology Acceptance Model in an Arabic Sample. Electronic Journal of E-Learning, 13(5), 408-426.

Burgstahler, S. (2011). Universal Design: Implications for Computing Education. ACM Transactions on Computing Education, 11(3), 1-17. doi:10.1145/2037276.2037283

CAST. (2011). Universal Design for Learning (UDL) Guidelines version 2.0. Wakefeild, MA: Author.

CAST. (2015). CAST. Retrieved from http://www.cast.org/our-work/aboutudl.html\#.VW1yKyFViko.

Center for Universal Design. (2015). Retrieved from http://www.ncsu.edu/ncsu/design/cud/about_ud/about_ud.htm.

Chekfoung, T., Lily, S., \& Kecheng, L. (2015). BIG DATA ARCHITECTURE FOR PERVASIVE HEALTHCARE: A LITERATURE REVIEW. Twenty-Third European Conference on Information Systems (ECIS), Münster, Germany, 2015, 1-19.

Coffield, F., Moseley, D., Hall, E., \& Ecclestone, K. (2004). Learning styles and pedagogy in post16 learning: A systematic and critical review.

Journal of the Scholarship of Teaching and Learning, Vol. 16, No. 3, June 2016.

josotl.indiana.edu [Type here] 
Courey, S. J., Tappe, P., Siker, J., \& LePage, P. (2012). Improved Lesson Planning with Universal Design for Learning (UDL). Teacher Education and Special Education: The Journal of the Teacher Education Division of the Council for Exceptional Children. doi:10.1177/0888406412446178

Coyne, P., Pisha, B., Dalton, B., Zeph, L. a., \& Smith, N. C. (2012). Literacy by Design: A Universal Design for Learning Approach for Students with Significant Intellectual Disabilities. Remedial and Special Education, 33(3), 162-172. doi:10.1177/0741932510381651

Davies, P. L., Schelly, C. L., \& Spooner, C. L. (2012). Measuring the Effectiveness of Universal Design for Learning Intervention in Postsecondary Education. Journal of Postsecondary Education and Disability, 26(3), 195-220.

Felder, R. (1996). Matters of style. ASEE Prism, 6(4), 18-23.

Graf, S. (2007). Adaptivity in learning management systems focussing on learning styles. $P h D$ Dissertation, (December 2007).

Hall, T. E., Cohen, N., Vue, G., \& Ganley, P. (2015). Addressing Learning Disabilities with UDL and Technology: Strategic Reader. Learning Disability Quarterly, 38(2), 72-83. doi:10.1177/0731948714544375

He, Y. (2014). Universal Design for Learning in an Online Teacher Education Course : Enhancing Learners' Confidence to Teach Online. MERLOT Journal of Online Learning and Teaching, 10(2), 283-298.

John Clarkson, P., \& Coleman, R. (2015). History of Inclusive Design in the UK. Applied Ergonomics, 46, 235-247. doi:10.1016/j.apergo.2013.03.002

Kennedy, M. J., Thomas, C. N., Meyer, J. P., Alves, K. D., \& Lloyd, J. W. (2014). Using EvidenceBased Multimedia to Improve Vocabulary Performance of Adolescents with LD: A UDL Approach. Learning Disability Quarterly, 37(2), 71-86. doi:10.1177/0731948713507262

King-Sears, M. E., Johnson, T. M., Berkeley, S., Weiss, M. P., Peters-Burton, E. E., Evmenova, a. S., \& Hursh, J. C. (2015). An Exploratory Study of Universal Design for Teaching Chemistry to Students with and Without Disabilities. Learning Disability Quarterly, 38(2), 84-96. doi:10.1177/0731948714564575

Kumar, K. L., \& Wideman, M. (2014). Accessible by Design: Applying UDL Principles in a First Year Undergraduate Course. Canadian Journal of Higher Education, 44(1), 125-147.

Liakou, M., \& Manousou, E. (2015). Distance education for people with visual impairments. European Journal of Open, Distance and E-Learning, 18(1), 73-85.

Liyanagunawardena, T. R., Adams, A. A., \& Williams, S. A. (2013). MOOCs : A systematic study of the published literature 2008-2012. The International Review of Research in Open and Distributed Learning, 14(3), 203-227.

Mangiatordi, A., \& Serenelli, F. (2013). Universal design for learning: A meta-analytic review of 80 abstracts from peer reviewed journals. Research on Education and Media, 5(1), 109-118.

Mavrou, K., \& Symeonidou, S. (2014). Employing the principles of universal design for learning to deconstruct the Greek-Cypriot new national curriculum. International Journal of Inclusive Education, 18(9), 918-933. doi:10.1080/13603116.2013.859308

Journal of the Scholarship of Teaching and Learning, Vol. 16, No. 3, June 2016. josotl.indiana.edu [Type here] 
Mayer, R. E. (2011). Does styles research have useful implications for educational practice? Learning and Individual Differences, 21(3), 319-320. doi:10.1016/j.lindif.2010.11.016

McGhie-Richmond, D., \& Sung, A. N. (2012). Applying Universal Design for Learning to Instructional Lesson Planning. International Journal of Whole Schooling, 9(1), 43-59.

Özyurt, Ö., \& Özyurt, H. (2015). Learning style based individualized adaptive e-learning environments: Content analysis of the articles published from 2005 to 2014. Computers in Human Behavior, 52, 349-358. doi:10.1016/j.chb.2015.06.020

Pashler, H., Mcdaniel, M., Rohrer, D., \& Bjork, R. (2009). Learning Styles Concepts and Evidence. Psychological Science in the Public Interest, 9(3), 105-119.

Rao, K., Ok, M. W., \& Bryant, B. R. (2014). A Review of Research on Universal Design Educational Models. Remedial and Special Education, 35(3), 153-166. doi:10.1177/0741932513518980

Rose, D. H., \& Meyer, A. (2002). Teaching Every Student in the Digital Age: Universal Design for Learning. (V. A. Alexandria, Ed.).

Rose, D., Harbour, W., Johnston, C. S., Daley, S., \& Abarbanell, L. (2006). Universal Design for Learning in Postsecondary Education. Journal of Postsecondary Education and Disability (Vol. 19).

Smith, F. G. (2012). Analyzing a College Course That Adheres to the Universal Design for Learning (UDL) Framework. Journal of the Scholarship of Teaching and Learning, 12(3), 31-61.

Smith, S. J., \& Harvey, E. E. (2014). K-12 online lesson alignment to the principles of Universal Design for Learning: the Khan Academy. Open Learning: The Journal of Open, Distance and ELearning, 29(3), 222-242. doi:10.1080/02680513.2014.992402

Truong, H. M. (2015). Integrating learning styles and adaptive e-learning system: Current developments, problems and opportunities. Computers in Human Behavior. doi:10.1016/j.chb.2015.02.014

Vanderheyden, K., \& De Baets, S. (2015). Does cognitive style diversity affect performance in dyadic student teams? Learning and Individual Differences, 38, 143-150. doi:10.1016/j.lindif.2015.01.006

Willingham, D. T., Hughes, E. M., \& Dobolyi, D. G. (2015). The Scientific Status of Learning Styles Theories. Teaching of Psychology, 42(3), 266-271. doi:10.1177/0098628315589505

Journal of the Scholarship of Teaching and Learning, Vol. 16, No. 3, June 2016. 